Effect of Small Variation in the Composition of Plates and Weld Filler Wires on the General Corrosion Rate of $\mathrm{Ni}-\mathrm{Cr}$-Mo Alloys

David V. Fix, John C. Estill, Raúl B. Rebak

February 10, 2005

ASME Pressure Vessels \& Piping Division Conference Denver, CO, United States July 17, 2005 through July 21, 2005 
This document was prepared as an account of work sponsored by an agency of the United States Government. Neither the United States Government nor the University of California nor any of their employees, makes any warranty, express or implied, or assumes any legal liability or responsibility for the accuracy, completeness, or usefulness of any information, apparatus, product, or process disclosed, or represents that its use would not infringe privately owned rights. Reference herein to any specific commercial product, process, or service by trade name, trademark, manufacturer, or otherwise, does not necessarily constitute or imply its endorsement, recommendation, or favoring by the United States Government or the University of California. The views and opinions of authors expressed herein do not necessarily state or reflect those of the United States Government or the University of California, and shall not be used for advertising or product endorsement purposes. 


\title{
EFFECT OF SMALL VARIATION IN THE COMPOSITION OF PLATES AND WELD FILLER WIRES ON THE GENERAL CORROSION RATE OF Ni-Cr-Mo ALLOYS
}

\author{
David V. Fix \\ John C. Estill \\ Raúl B. Rebak \\ Lawrence Livermore National Laboratory \\ 7000 East Ave, L-631 \\ Livermore, California, 94550 USA
}

\section{ABSTRACT}

The ASTM standard B 575 provides the requirements for the chemical composition of Nickel-Chromium-Molybdenum (Ni-Cr-Mo) alloys such as Alloy 22 (N06022) and Alloy 686 (N06686). The compositions of each element are given in a range. For example, the content of Mo is specified from 12.5 to 14.5 weight percent for Alloy 22 and from 15.0 to 17.0 weight percent for Alloy 686. It was important to determine how the corrosion rate of welded plates of Alloy 22 using Alloy 686 weld filler metal would change if heats of these alloys were prepared using several variations in the composition of the elements even though still in the range specified in B 575. All the material used in this report were especially prepared at Allegheny Ludlum Co. Seven heats of plate were welded with seven heats of wire. Immersion corrosion tests were conducted in a boiling solution of sulfuric acid plus ferric sulfate (ASTM G 28 A) using both as-welded (ASW) coupons and solution heat-treated (SHT) coupons. Results show that the corrosion rate was not affected by the chemistry of the materials within the range of the standards.

Keywords: N06022, Heat-to-Heat Variability, Corrosion Rate, solution heat treatment, ASTM G 28A

\section{INTRODUCTION}

The composition of engineering alloys such as Alloy 22 (N06022) and 686 (N06686) is given by ASTM standards (B 575). ${ }^{1}$ When the alloys are commercially produced their chemical composition can vary slightly from heat to heat while still within the boundaries of the standard specification. It was of interest to determine if a small variation in the composition of the alloys was important enough, for example, to result in a different corrosion resistance.

The fabrication history of the original welded plates is given elsewhere. ${ }^{2-3}$ Basically, wrought plates with seven different heats (A through G) of Alloy 22 (Table 1) were welded with weld wire from seven different heats (1 through 7) of Alloy 686 (Table 2). The Alloy 22 plates were nominally 1inch thick. The Alloy 686 or ERNiCrMo-14 weld wire was 0.0625 -inch diameter and met the specifications of ASME SFA-5.14. ${ }^{4}$ The welding method was gas tungsten arc welding (GTAW). Welded specimens from these 49 resulting plates were studied both in the as-welded (ASW) condition and in the solution heat-treated (SHT) (annealed) condition. The solution annealing was carried in air at $2075^{\circ} \mathrm{F}$ for $1 \mathrm{~h}$ plus rapid cooling (water spraying). ${ }^{2-3}$ Immersion corrosion tests were carried out in a boiling solution of sulfuric acid and ferric sulfate (ASTM G 28 A). ${ }^{5}$ 


\section{EXPERIMENTAL}

\section{Preparation of the Corrosion Coupons}

The test material was delivered to Lawrence Livermore National Laboratory in the form of 1-inch thick welded plates. There were two types of plate strips: (1) As-Welded (ASW) and (2) ASW plus solution heat-treated (SHT). The welding and heat treatment were carried out in the primary metal producer plant. ${ }^{2-3}$ Table 3 shows the identification of the coupons prepared from the welded plates. These plates were water-jet cut perpendicularly to the weld in approximately 1inch thick slices. Then, the test coupons were abrasion wheel cut to immersion corrosion testing sizes from the plate slices. Each coupon contained the weld seam on its center and base material at each side of the weld seam. The testing coupons were approximately 0.5 to 1 -inch wide, 0.25 to 0.5 -inch thick and 2 -inch long. These sizes were constrained by the testing apparatus (ASTM G 28) and specimen holder. ${ }^{5}$ That is, each coupon had six surfaces. Five of the surfaces were as-cut surfaces (abrasion wheel of water jet) and one surface (top surface) had the mill finish condition. In the case of the ASW + SHT coupons the top surface had also the characteristic black annealing oxide scale.

The surface area of the coupons varied generally from 20 to $35 \mathrm{~cm}^{2}$ and the weight in the varied from 30 to $60 \mathrm{~g}$. The coupons were degreased in acetone, rinsed in de-ionized water and let dry. Each coupon was labeled, photographed, dimensioned and weighed three times before the corrosion testing started. In the initial plan it was intended to corrosion test 98 specimens, one for each condition of chemistry and heat treatment. However, at the time of this report, the tests were only approximately $2 / 3$ finished due to a laboratory eviction.

\section{Immersion Corrosion Tests (G 28 A)}

ASTM G 28 A method measures the susceptibility of nickel alloys to intergranular attack. It is often used to determine preferential intergranular attack near welds or in heat affected zones (HAZ). The guidelines are specified in the Annual Book of ASTM standards. ${ }^{5}$ Figure 1 shows the setting for the tests. The ASTM G 28 A method for Alloy 22 consists in immersing coupons of the alloy for $24 \mathrm{~h}$ in a boiling solution of $42 \mathrm{~g} / \mathrm{L} \mathrm{Fe}{ }_{2}\left(\mathrm{SO}_{4}\right)_{3}$ (ferric sulfate) plus $50 \% \mathrm{H}_{2} \mathrm{SO}_{4}$ (sulfuric acid). This is a highly acidic and oxidizing solution. The difference in the mass of the coupon between before and after the test can be used to calculate the uniform corrosion rate (Equation 1) ${ }^{5}$

$C R(\mathrm{~mm} / \mathrm{y})=\frac{8.76 \times 10^{4} \cdot\left(W_{i}-W_{f}\right)(\mathrm{g})}{A\left(\mathrm{~cm}^{2}\right) \cdot t(h) \cdot d\left(\mathrm{~g} \cdot \mathrm{cm}^{-3}\right)}$
Where $\mathrm{W}_{\mathrm{i}}$ is the initial mass of the coupon, $\mathrm{W}_{\mathrm{f}}$ is the mass of the coupon after the 24-h immersion test, A is the surface area of the coupon, $t$ is the testing time $(24 \mathrm{~h})$ and $d$ is the density of Alloy $22\left(8.69 \mathrm{~g} / \mathrm{cm}^{3}\right) .{ }^{5}$ Only one coupon was tested for each base-weld combination.

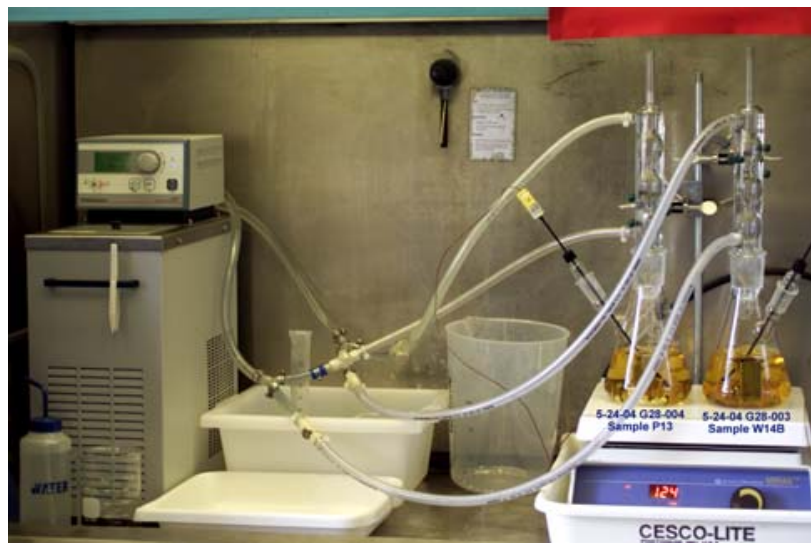

Figure 1. Set-up for Immersion Corrosion Testing

\section{PRELIMINARY RESULTS AND DISCUSSION}

The results discussed here are preliminary since the entire matrix of the tests has not been completed yet. The testing coupons were approximately parallelepipeds, that is, they had six faces. Five faces were as-cut faces and were of the same nature for both types of coupons (ASW and ASW + SHT). Whenever comparing surface characteristics after corrosion testing only the face of interest (top face) is discussed. Figure 2 shows the general appearance of the top face of ASW 28R5 coupon, before and after the immersion test. Coupon 28R5 corresponded to Base Heat G welded with Wire Heat 7 (Table 3 ). Before the test, the coupon had a slight heat tint in the heat affected zone (HAZ) area. After the test, the HAZ appeared darker than the rest of the coupon, suggesting enhanced attack in this area. This can be seen as two darker bands at each side and parallel to the weld seam (Figure 2). The attack in the HAZ is generally intergranular attack (IGA).

Figure 3 shows the general appearance of the top face of the ASW + SHT 73R5 coupon. Before the immersion test, the coupon was covered by a dark (black + dark green) oxide scale. After the immersion test, most of the oxide scale was washed away and only the weld seam contained remnants of this scale. Many times there were islands of uneven attack in the weld seam within the area covered by the scale. In some weld seams, cavities were found. It is not clear if these cavities were formed during the immersion tests of were weld porosity formed during welding. The black HAZ bands of IGA present in the 
ASW coupons (Figure 2) were absent in the ASW + SHT coupons (Figure 3).

28R5-G28-1-F

Aug 17, 2004

Pre Test
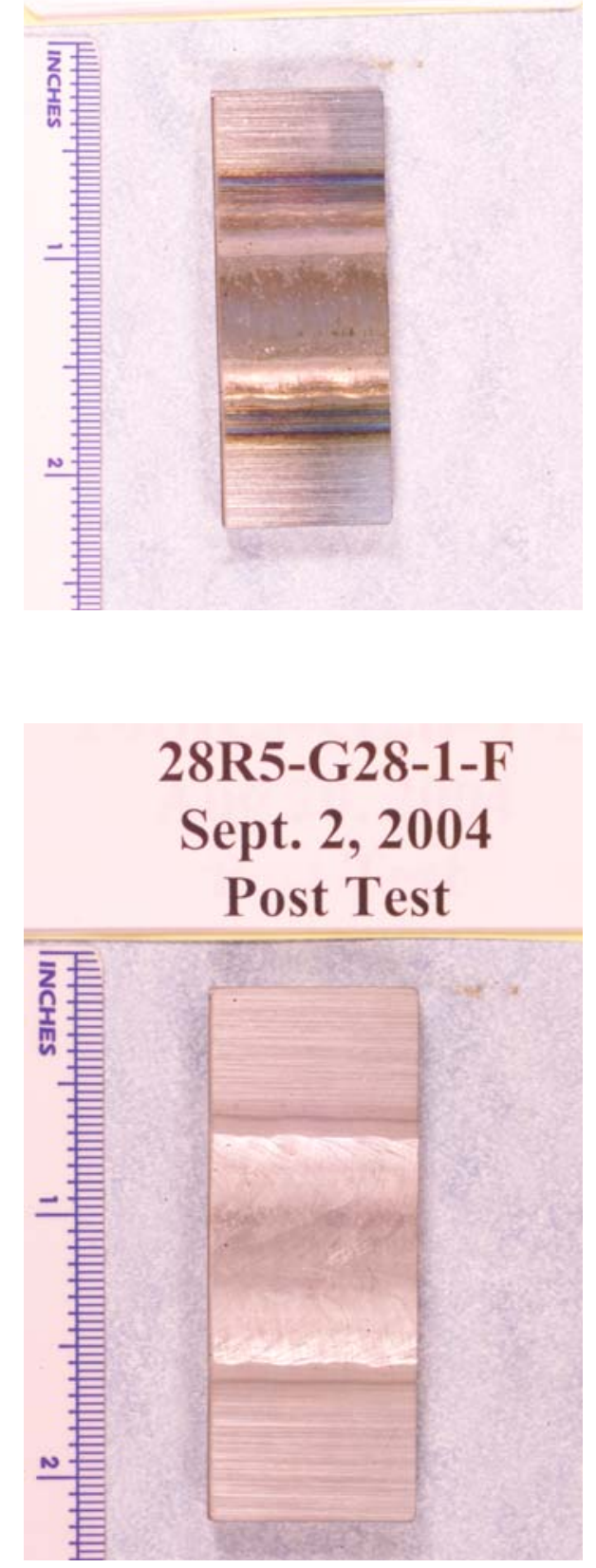

Figure 2. ASW Coupon 28R5 before (top) and after (above) the immersion test
73R5-G28-1-F

Sept. 9, 2004

Pre Test

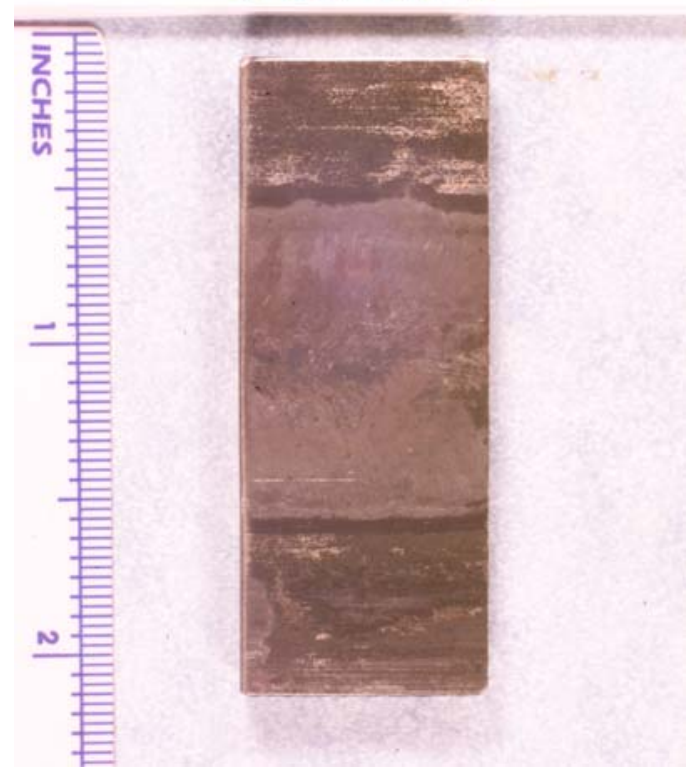

\section{R5-G28-1-F \\ Sept. 16, 2004 \\ Post Test}

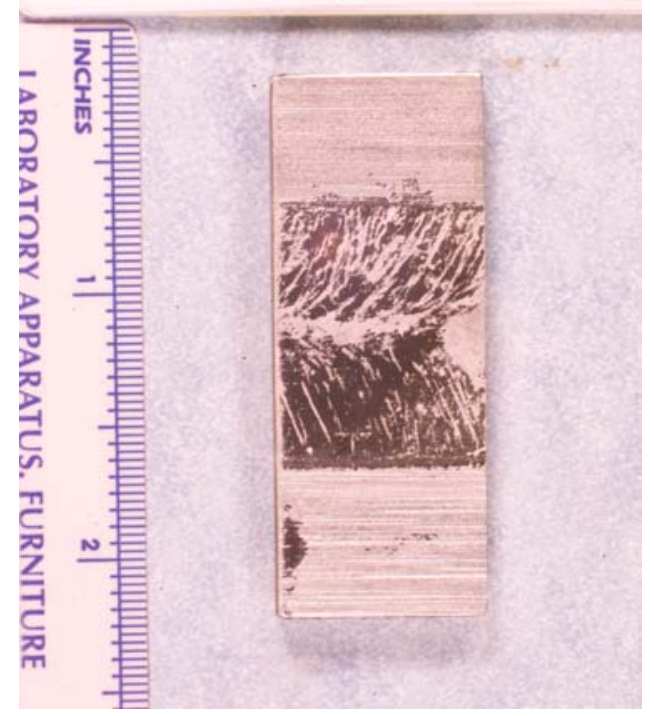

Figure 3. ASW + SHT Coupon 73R5 before (top) and after (above) the immersion tests 
Table 4 shows the corrosion rate results from the immersion testing. The tests are approximately $2 / 3$ complete (there are still 35 coupons -out of 98 - to be tested). Figure 4 shows the corrosion rate for all the ASW coupons. Corrosion rate data are single values for each base-weld wire chemistry combination. Nonetheless, it is apparent from Figure 4 that the corrosion rate for most plate-weld wire pairs was between 1.0 and $1.1 \mathrm{~mm} /$ year. The corrosion rate of wrought and welded Alloy 22 is approximately $1 \mathrm{~mm} /$ year (40 mpy). ${ }^{6-11}$ Figure 4 shows that there were a few coupons in the middle of the graph that had slightly higher corrosion rates. These coupons were prepared using Weld Wire 4 and base metal with "rich" chemistry (Heats E, F and G) (Table 1). It is likely that the rich chemistries accelerated the precipitation of deleterious ordered phases during welding, which later increased the corrosion rate of the coupons in the HAZ.

Figure 5 shows the corrosion rates for the ASW + SHT coupons. Figure 6 shows comparatively the corrosion rates for the ASW coupons (Figure 4) and the ASW + SHT coupons (Figure 5). In general the corrosion rates of the ASW + SHT coupons were higher than the ASW coupons, probably because of the dissolution (or detachment) of the oxide scale from the top surface of the ASW + SHT coupons (Figure 3). Also, the testing electrolyte was darker after the tests for the ASW + SHT coupons than for the ASW coupons, suggesting more contamination of the electrolyte in the case of the ASW + SHT coupons. Mori et al. have shown that the corrosion rate of $\mathrm{Ni}-$ Cr-Mo alloys in ASTM G 28 solutions is highly dependent on the surface finish of the coupons. ${ }^{12}$ Figure 5 shows that the corrosion rate seemed to increase for higher number weld wire heats. The higher number weld wire heats correspond to "richer" chemistries (Table 2), that is, the material that contained the highest amounts of $\mathrm{Cr}$, Mo and W. Again, similarly to the data for ASW coupons (Figure 4), the ASW + SHT coupons welded with Wire 4 had higher than expected corrosion rates.

It has been reported previously that the Base Heat $G$ did not meet the elongation to failure during mechanical testing required for wrought N06022 material. ${ }^{2-3}$ Weldments produced using Wire 4 produced poor mechanical properties of the material (e.g. reduced tensile strength and low elongation to failure). ${ }^{2-3}$ Poor mechanical properties of welded plates were also reported using wires 4 and 7 with plate D. ${ }^{2-3}$ For most of the welded plates, a SHT process increased the Charpy toughness of the materials. The toughness of the welded coupons, both ASW and SHT were the lowest for the E, F and $\mathrm{G}$ plates welded with wire $4 .{ }^{2-3}$ The poor performance of weld Wire 4 was attributed to the high content of residual elements. ${ }^{2-3}$
Figure 7 shows the relationship between the corrosion rate of the ASW coupons and the weight percent factor (WPF) $\% \mathrm{Cr} /(\% \mathrm{Mo}+\% \mathrm{~W})$. The WPF was calculated by averaging the weight percent content of the elements in the base (N06022) and weld seam (N06686). Figure 7 shows that, as expected, as the WPF increases the corrosion rate of a Ni-Cr-Mo alloy in an acidic oxidizing solution decreases. ${ }^{12,13}$

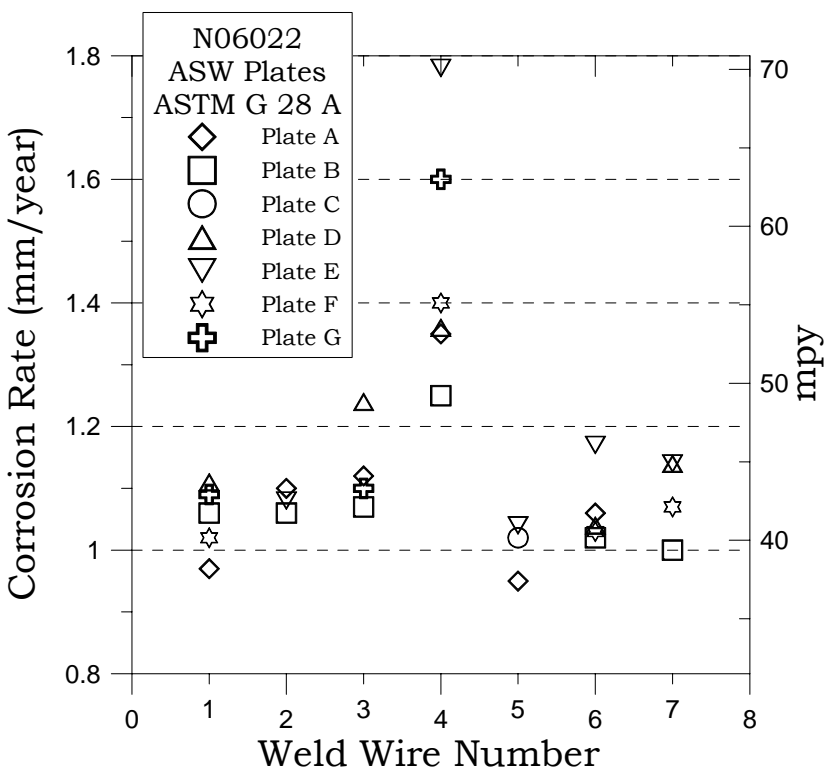

Figure 4. Corrosion Rate for ASW Coupons

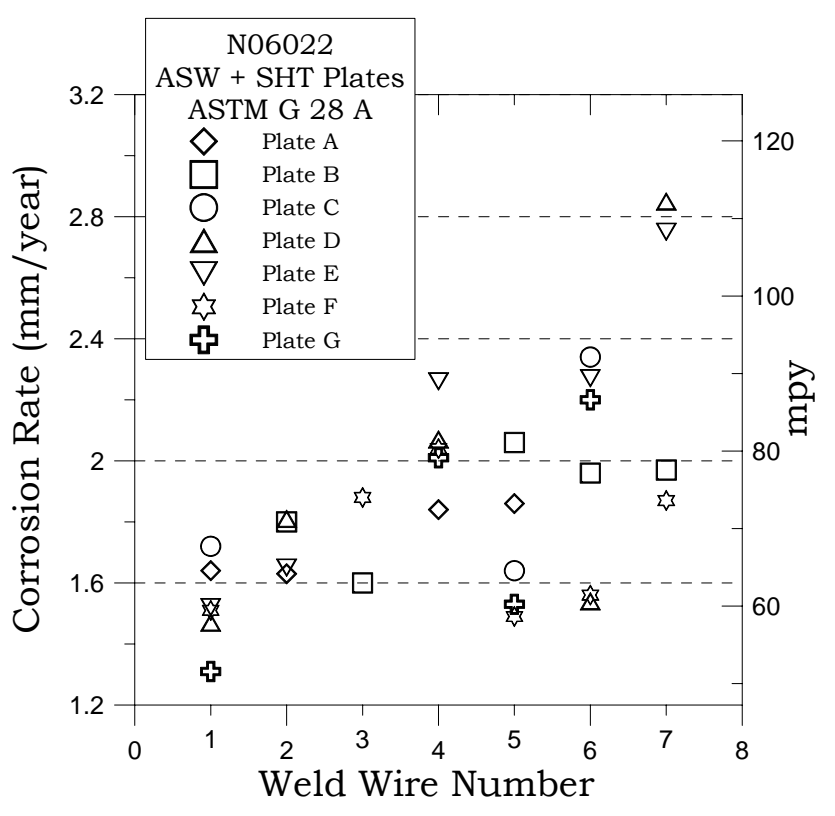

Figure 5. Corrosion Rate for ASW + SHT Coupons 


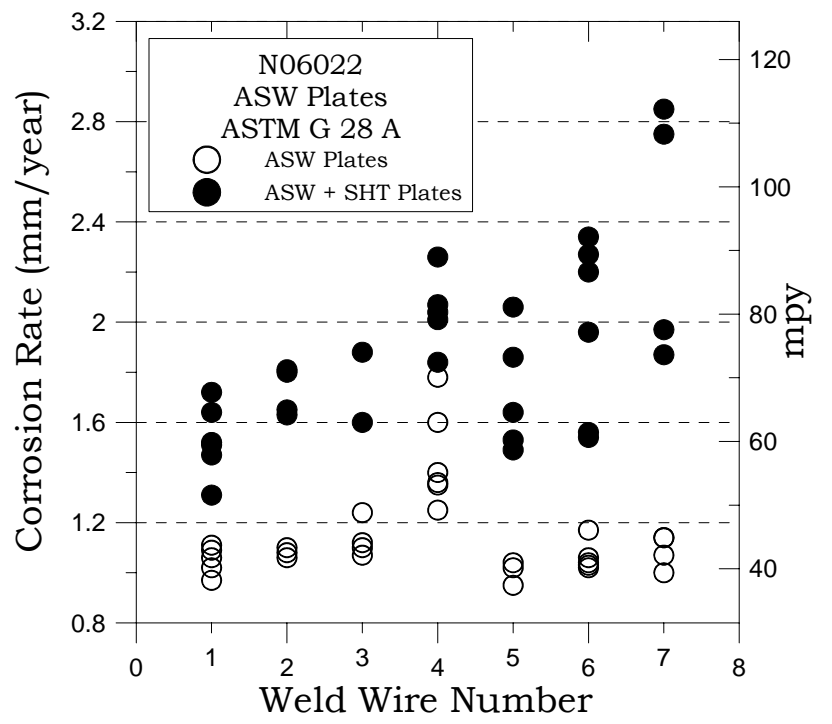

Figure 6. Corrosion Rate for ASW and ASW + SHT Coupons

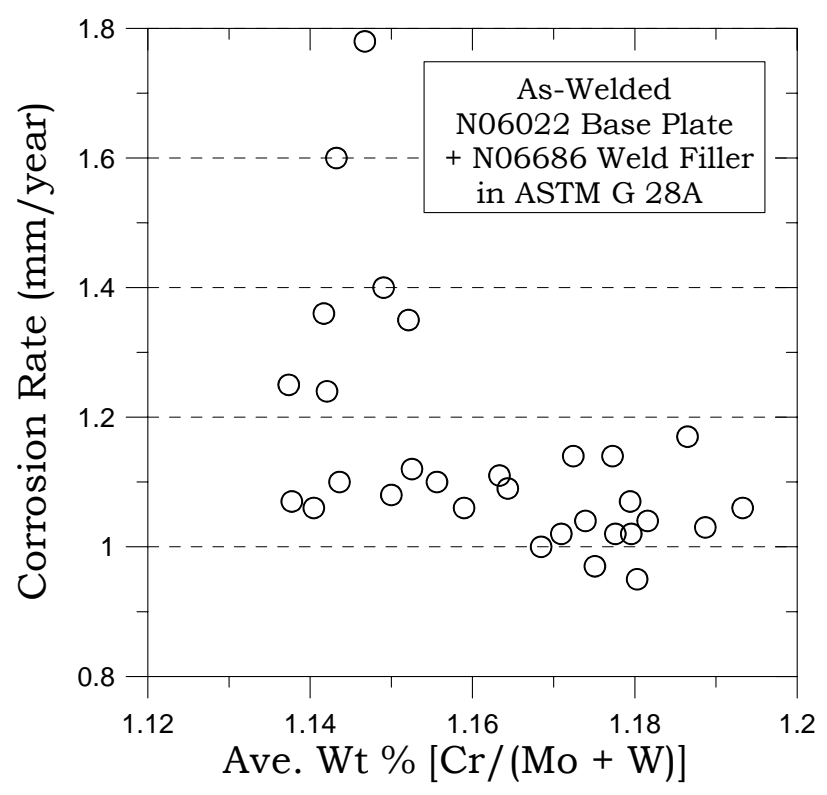

Figure 7. Corrosion Rate for ASW Coupons as a function of the WPF

\section{CONCLUDING REMARKS}

Results from the current testing shows that variations in the chemistry of both Alloy 22 and Alloy 686 within the range provided by the guiding standards do not affect the corrosion performance of these alloys. This is not surprising since when a primary metal producer develops and patents a new alloy, many different chemical compositions of the developed alloy are tested both for mechanical properties and for corrosion resistance in several types of electrolytes, generally from acidic reducing to acidic oxidizing. Later, the ranges of the chemical composition that give the desirable mechanical and corrosion properties are written into the standards which are presented to and accepted by societies such as ASTM of ASME. That is, the fact that the current test program failed to detect a change in the corrosion resistance of the alloys when their composition is varied within the margins of the approved standard could have been predicted based on the industrial experience. Even though some rich chemical compositions (when all important alloying elements such as $\mathrm{Cr}$, Mo and $\mathrm{W}$ and maxed out) gave slightly different behavior, it is unlikely that a commercial heat will have the maximum content of all the important elements, purely for economical reasons.

\section{CONCLUSIONS}

- Corrosion rate of as-welded coupons of Alloy 22 plates with Alloy 686 wires in ASTM G 28 A solution were comparable to published data and in the order of 1 $\mathrm{mm} /$ year (40 mpy)

- The corrosion rate of welded plus solution heat treated $($ ASW + SHT) coupons were higher than for ASW coupons, because the former contained an oxide scale in the surface that disintegrated during corrosion testing

- Corrosion rate results depended only slightly with the chemistry of both the base alloy and the weld wire

- In the range of the accepted chemistry of commercial materials the corrosion rate of one heat usually is indistinguishable from the corrosion rate of another heat

\section{ACKNOWLEDGMENTS}

This work was partially performed under the auspices of the U. S. Department of Energy by the University of California Lawrence Livermore National Laboratory under contract W-7405-Eng-48. The work was supported by the Yucca Mountain Project, which is part of the DOE Office of Civilian Radioactive Waste Management (OCRWM).

\section{DISCLAIMER}

This document was prepared as an account of work sponsored by an agency of the United States Government. Neither the United States Government nor the University of California nor any of their employees, makes any warranty, express or 
implied, or assumes any legal liability or responsibility for the accuracy, completeness, or usefulness of any information, apparatus, product, or process disclosed, or represents that its use would not infringe privately owned rights. Reference herein to any specific commercial product, process, or service by trade name, trademark, manufacturer, or otherwise, does not necessarily constitute or imply its endorsement, recommendation, or favoring by the United States Government or the University of California. The views and opinions of authors expressed herein do not necessarily state or reflect those of the United States Government or the University of California, and shall not be used for advertising or product endorsement purposes.

\section{REFERENCES}

1. ASTM International, Annual Book of ASTM Standards, Volume 02.04 "Non-Ferrous Metals" Standard B-575 (West Conshohocken, PA: ASTM International, 2004).

2. Allegheny Technologies, Report on "Nickel-Based Alloy Weld Filler Material and Base Metal Composition Test Program', Report 004223-REV 000, March 2004 (Allegheny Technologies, 2004: Albany, OR).

3. Waste Package and Drip Shield Corrosion, Technical Basis Document $\mathrm{N}^{\circ}$ 6, Appendix $\mathrm{T}$ "Microstructural and Compositional Variations of Alloy 22," June 2004 (BSC, 2004: Las Vegas, NV)
4. ASME (American Society of Mechanical Engineers), 2001 ASME Boiler and Pressure Vessel Code (ASME, 2001, 2001: New York, NY).

5. ASTM International, Annual Book of ASTM Standards, Volume 03.02 "Wear and Erosion; Metal Corrosion" p. 91 (West Conshohocken, PA: ASTM International, 2004).

6. Haynes International Inc., "Hastelloy C-22 Alloy," Product Brochure H-2019E (1997).

7. R. B. Rebak and N. E. Koon, Corrosion/1998, Paper 153 (NACE International, 1998: Houston, TX).

8. R. B. Rebak, N. E. Koon, J. R. Dillman, P. Crook and T. S. E. Summers, Corrosion/2000, Paper 00181 (NACE International, 2000: Houston, TX).

9. R. B. Rebak, T. S. E. Summers, T. Lian, R. M. Carranza, J. R. Dillman, T. Corbin and P. Crook "Effect of Thermal Aging on the Corrosion Behavior of Wrought and Welded Alloy 22," Corrosion/2002, Paper 02542 (NACE International, 2002: Houston, TX).

10. R. B. Rebak and P. Crook, PVP-Vol. 449, p. 111 (ASME, 2002: New York, NY).

11. R. B. Rebak, ASM Metals Handbook, Vol. 13A, p. 279 (ASM International, 2003, Metals Park, OH).

12. G. Mori, S. Sutthiruangwong, M. Czerny and T. Partlic, Corrosion, 60, 1082 (2004).

13. R. B. Rebak and P. Crook, PVP-Vol. 483, p. 131 (ASME, 2004: New York, NY). 
Table 1. Approximate Average Chemical Composition of the N06022 Plates (Heats A-G)

\begin{tabular}{|c|c|c|c|c|c|c|c|}
\hline Element $\downarrow$ Heat $\rightarrow$ & $\mathbf{A}$ & $\mathbf{B}$ & $\mathbf{C}$ & D & $\mathbf{E}$ & $\mathbf{F}$ & G \\
\hline $\mathrm{Ni}$ & 61.6 & 59.6 & 58.5 & 56.00 & 56.3 & 58.1 & 53.9 \\
\hline $\mathrm{Cr}$ & 20.3 & 20.8 & 21.1 & 21.3 & 21.6 & 21.8 & 22.5 \\
\hline Mo & 12.7 & 13.3 & 13.1 & 13.6 & 13.7 & 13.8 & 14.2 \\
\hline W & 2.7 & 3.0 & 3.0 & 3.0 & 3.0 & 3.0 & 3.4 \\
\hline $\mathrm{Fe}$ & 2.5 & 3.0 & 4.0 & 3.0 & 5.0 & 3.0 & 5.8 \\
\hline Co & 0.15 & ND & ND & 2.23 & ND & 0.03 & ND \\
\hline $\mathrm{Mn}$ & 0.02 & 0.02 & 0.01 & 0.4 & 0.04 & 0.02 & 0.03 \\
\hline $\mathrm{Al}$ & 0.18 & 0.15 & 0.17 & 0.15 & 0.15 & 0.19 & 0.20 \\
\hline V & ND & ND & ND & 0.25 & 0.01 & 0.01 & 0.01 \\
\hline $\mathrm{Cu}$ & 0.01 & 0.01 & ND & 0.02 & ND & 0.01 & ND \\
\hline $\mathrm{Si}$ & 0.03 & 0.03 & 0.03 & 0.07 & 0.04 & 0.05 & 0.05 \\
\hline $\mathrm{C}$ & 0.004 & 0.004 & 0.006 & 0.005 & 0.01 & 0.014 & 0.007 \\
\hline $\mathrm{S}$ & 0.0003 & ND & ND & ND & ND & ND & ND \\
\hline $\mathrm{P}$ & 0.003 & 0.004 & 0.004 & ND & 0.006 & 0.005 & 0.006 \\
\hline \multicolumn{8}{|c|}{$\mathrm{ND}=$ Not Detected (Below the Detection Limit) } \\
\hline & & & & & & & \\
\hline
\end{tabular}

Table 2. Approximate Average Chemical Composition of the N06686 Weld Wires (1-7)

\begin{tabular}{|c|c|c|c|c|c|c|c|}
\hline Element $\downarrow$ Heat $\rightarrow$ & 1 & 2 & 3 & 4 & 5 & 6 & 7 \\
\hline $\mathrm{Ni}$ & 61.9 & 60.4 & 58.8 & 53.6 & 57.8 & 56.8 & 55.6 \\
\hline $\mathrm{Cr}$ & 19.3 & 19.8 & 20.5 & 20.6 & 21.6 & 22.3 & 22.9 \\
\hline Mo & 15.1 & 15.8 & 16.3 & 16.3 & 16.3 & 16.3 & 16.8 \\
\hline $\mathrm{W}$ & 3.2 & 3.5 & 3.7 & 3.8 & 3.8 & 4.0 & 4.3 \\
\hline $\mathrm{Fe}$ & ND & 0.42 & 0.39 & 4.03 & 0.28 & 0.35 & 0.14 \\
\hline Co & ND & ND & ND & 0.02 & ND & ND & ND \\
\hline $\mathrm{Mn}$ & ND & ND & ND & 0.89 & ND & ND & ND \\
\hline $\mathrm{Al}$ & 0.15 & 0.16 & 0.17 & 0.06 & 0.18 & 0.16 & 0.16 \\
\hline $\mathrm{V}$ & ND & ND & ND & 0.11 & ND & ND & ND \\
\hline $\mathrm{Cu}$ & ND & 0.01 & 0.01 & 0.43 & 0.01 & 0.01 & 0.01 \\
\hline $\mathrm{Si}$ & 0.02 & 0.02 & 0.03 & 0.08 & 0.02 & 0.03 & 0.03 \\
\hline $\mathrm{C}$ & 0.004 & 0.005 & 0.002 & 0.005 & 0.001 & 0.001 & 0.002 \\
\hline $\mathrm{S}$ & ND & ND & ND & ND & ND & ND & ND \\
\hline $\mathrm{P}$ & ND & 0.006 & 0.007 & ND & 0.008 & 0.008 & 0.01 \\
\hline \multicolumn{8}{|c|}{$\mathrm{ND}=$ Not Detected (Below the Detection Limit) } \\
\hline & & & & & & & \\
\hline
\end{tabular}


Table 3. Welded Plate Designation Based on the Chemistry of Base Plate and Weld Wire

\begin{tabular}{|c|c|c|c|c|c|}
\hline $\begin{array}{c}\text { Chemistry of } \\
\text { Base and Weld }\end{array}$ & ASW Plate ID & $\begin{array}{l}\text { ASW + SHT } \\
\text { Plate ID }\end{array}$ & $\begin{array}{c}\text { Chemistry of } \\
\text { Base and Weld }\end{array}$ & ASW Plate ID & $\begin{array}{c}\text { ASW + SHT } \\
\text { Plate ID }\end{array}$ \\
\hline A1 & $4 \mathrm{R} 5$ & 5R5 & E1 & $8 \mathrm{R} 5$ & 9R5 \\
\hline A2 & 14R5 & 15R5 & E2 & 18R5 & 19R5 \\
\hline A3 & 64R5 & $65 \mathrm{R} 5$ & E3 & 70R5 & 71R5 \\
\hline A4 & $84 \mathrm{R} 5$ & $85 \mathrm{R} 5$ & E4 & 190R5 & 91R5 \\
\hline A5 & 42R5 & $43 \mathrm{R} 5$ & E5 & 46R5 & 47R5 \\
\hline A6 & 50R5 & 51R5 & E6 & 58R5 & 59R5 \\
\hline A7 & 30R5 & $31 \mathrm{R} 5$ & E7 & $34 \mathrm{R} 5$ & 135R5 \\
\hline B1 & $6 \mathrm{R} 5$ & $7 \mathrm{R} 5$ & F1 & $2 \mathrm{R} 5$ & $3 R_{5}$ \\
\hline B2 & 17R5 & 16R5 & F2 & $12 \mathrm{R} 5$ & 13R5 \\
\hline B3 & 66R5 & 67R5 & F3 & $72 \mathrm{R} 5$ & 73R5 \\
\hline B4 & $82 \mathrm{R} 5$ & $83 R 5$ & F4 & $88 \mathrm{R} 5$ & $89 \mathrm{R} 5$ \\
\hline B5 & 44R5 & 45R5 & F5 & $38 \mathrm{R} 5$ & $39 \mathrm{R} 5$ \\
\hline B6 & 56R5 & 57R5 & F6 & 54R5 & $55 \mathrm{R} 5$ \\
\hline B7 & $32 \mathrm{R} 5$ & $33 R 5$ & F7 & 26R5 & 127R5 \\
\hline $\mathrm{C} 1$ & 10R5 & 11R5 & G1 & 24R5 & 25R5 \\
\hline $\mathrm{C} 2$ & 120R5 & 21R5 & $\mathrm{G} 2$ & 122R5 & $23 \mathrm{R} 5$ \\
\hline $\mathrm{C} 3$ & 168R5 & 69R5 & G3 & 162R5 & $63 \mathrm{R} 5$ \\
\hline $\mathrm{C} 4$ & 92R5 & 93R5 & $\mathrm{G} 4$ & 98R5 & 99R5 \\
\hline $\mathrm{C} 5$ & 148R5 & 49R5 & G5 & 40R5 & 41R5 \\
\hline C6 & 60R5 & 61R5 & G6 & 52R5 & 53R5 \\
\hline C7 & $36 \mathrm{R} 5$ & 37R5 & G7 & 28R5 & 29R5 \\
\hline D1 & 94R5 & 95R5 & & & \\
\hline D2 & 96R5 & 97R5 & & & \\
\hline D3 & 80R5 & $81 \mathrm{R} 5$ & & & \\
\hline D4 & $86 \mathrm{R} 5$ & 87R5 & & & \\
\hline D5 & 78R5 & 79R5 & & & \\
\hline D6 & 74R5 & 75R5 & & & \\
\hline D7 & 176R5 & 177R5 & & & \\
\hline & & & & & \\
\hline
\end{tabular}


Table 4. Corrosion Rate of Coupons Prepared from Welded Plates

\begin{tabular}{|c|c|c|c|c|c|c|c|}
\hline $\begin{array}{c}\text { ASW } \\
\text { Plate ID }\end{array}$ & $\begin{array}{c}\text { Corrosion } \\
\text { Rate } \\
\text { (mm/year) }\end{array}$ & $\begin{array}{c}\text { ASW + } \\
\text { SHT } \\
\text { Plate ID }\end{array}$ & $\begin{array}{c}\text { Corrosion } \\
\text { Rate } \\
\text { (mm/year) }\end{array}$ & $\begin{array}{c}\text { ASW } \\
\text { Plate ID }\end{array}$ & $\begin{array}{c}\text { Corrosion } \\
\text { Rate } \\
\text { (mm/year) }\end{array}$ & $\begin{array}{l}\text { ASW + } \\
\text { SHT } \\
\text { Plate ID }\end{array}$ & $\begin{array}{c}\text { Corrosion } \\
\text { Rate } \\
\text { (mm/year) }\end{array}$ \\
\hline 4R5 & 0.97 & $5 \mathrm{R} 5$ & 1.64 & $8 \mathrm{R} 5$ & ND & 9R5 & 1.52 \\
\hline 14R5 & 1.10 & 15R5 & 1.63 & 18R5 & 1.08 & 19R5 & 1.65 \\
\hline 64R5 & 1.12 & 65R5 & ND & 70R5 & ND & 71R5 & ND \\
\hline 84R5 & 1.35 & $85 \mathrm{R} 5$ & 1.84 & 190R5 & 1.78 & 91R5 & 2.26 \\
\hline 42R5 & 0.95 & 43R5 & 1.86 & 46R5 & 1.04 & 47R5 & ND \\
\hline 50R5 & 1.06 & 51R5 & ND & 58R5 & 1.17 & 59R5 & 2.27 \\
\hline 30R5 & ND & 31R5 & ND & $34 \mathrm{R} 5$ & 1.14 & 135R5 & 2.75 \\
\hline $6 \mathrm{R} 5$ & 1.06 & 7R5 & ND & 2R5 & 1.02 & 3R5 & 1.51 \\
\hline 17R5 & 1.06 & 16R5 & 1.80 & $12 \mathrm{R} 5$ & ND & 13R5 & ND \\
\hline 66R5 & 1.07 & 67R5 & 1.60 & 72R5 & ND & $73 \mathrm{R} 5$ & 1.88 \\
\hline $82 \mathrm{R} 5$ & 1.25 & $83 \mathrm{R} 5$ & ND & $88 \mathrm{R} 5$ & 1.40 & $89 \mathrm{R} 5$ & 2.04 \\
\hline 44R5 & ND & 45R5 & 2.06 & $38 \mathrm{R} 5$ & ND & $39 \mathrm{R} 5$ & 1.49 \\
\hline 56R5 & 1.02 & 57R5 & 1.96 & 54R5 & 1.03 & 55R5 & 1.56 \\
\hline $32 \mathrm{R} 5$ & 1.00 & $33 \mathrm{R} 5$ & 1.97 & 26R5 & 1.07 & 127R5 & 1.87 \\
\hline 10R5 & ND & 11R5 & 1.72 & 24R5 & 1.09 & 25R5 & 1.31 \\
\hline 120R5 & ND & 21R5 & ND & 122R5 & ND & $23 \mathrm{R} 5$ & ND \\
\hline 168R5 & ND & 69R5 & ND & 162R5 & 1.10 & $63 \mathrm{R} 5$ & ND \\
\hline 92R5 & ND & 93R5 & ND & 98R5 & 1.60 & 99R5 & 2.01 \\
\hline 148R5 & 1.02 & 49R5 & 1.64 & 40R5 & ND & 41R5 & 1.53 \\
\hline 60R5 & ND & 61R5 & 2.34 & 52R5 & ND & 53R5 & 2.20 \\
\hline $36 \mathrm{R} 5$ & ND & $37 \mathrm{R} 5$ & ND & 28R5 & NA & 29R5 & ND \\
\hline 94R5 & 1.11 & 95R5 & 1.47 & & & & \\
\hline 96R5 & ND & 97R5 & 1.81 & & & & \\
\hline 80R5 & 1.24 & $81 \mathrm{R} 5$ & ND & & & & \\
\hline $86 \mathrm{R} 5$ & 1.36 & 87R5 & 2.07 & & & & \\
\hline 78R5 & ND & 79R5 & ND & & & & \\
\hline 74R5 & 1.04 & 75R5 & 1.54 & & & & \\
\hline 176R5 & 1.14 & 177R5 & 2.85 & & & & \\
\hline \multicolumn{8}{|c|}{ ND $=$ Not Determined Yet, NA = Not Available (Data lost) } \\
\hline & & & & & & & \\
\hline
\end{tabular}

